\title{
Corporate Governance, Institutional Ownership, and Their Effects on Financial Performance
}

\author{
Kristal Hykaj, PhD Candidate
}

Epoka University, Albania

doi: 10.19044/esj.2016.v12n25p46 URL:http://dx.doi.org/10.19044/esj.2016.v12n25p46

\begin{abstract}
This paper studies the 105 U.S. Equity Real Estate Investment Trusts for the period of 2007-2012, and explores the relationship between corporate governance, institutional ownership, and financial performance. The results are conclusive and show that the presence of women on the board of directors as well as the choice to opt for a classified board enhances the returns on assets and returns on equity. The second finding of this paper is that the percentage of stocks owned by the top 10 institutions, between the levels of $30 \%$ and $50 \%$, are associated with higher returns on assets and returns on equity.
\end{abstract}

Keywords: Corporate, governance, performance, regression

\section{Introduction}

This paper focuses on the impact of corporate governance and the presence of large institutional shareholders on the financial performance of Real Estate Investment Trusts (REITs). The field of corporate governance and how it affects a firm's performance has been widely studied by several authors. Bauer et al. (2009) conducted a research where they used a database of 5000 US firms. Thus, they found a strong and solid evidence of the effects of corporate governance on the financial performance of these firms. The authors, however, concluded that due to REITs having a special regulatory environment, the effects of corporate governance is limited. Yet, Fend et al. (2009) constructed a corporate governance index where they included the size of the board, the duality of the Chief Executive Officer's duties, and the presence of outside directors in the high boardroom. Subsequently, their conclusion was that such indicators have a positive and significant impact on the financial performance of firms as measured by the returns on assets.

Institutional ownership is another field where a lot of academic work has been carried out. Shleifer and Vishny (1986) were among the first to recognize the great incentives that institutional investors have in monitoring 
the management of firms. Thus, this is because the size of the investment is generally very large, which means that the monitoring costs will not be out weighted by the benefits of eliminating deviant managerial behaviors. Following the same line of reasoning, the paper released by Gorssman and Hart (1980) noted that the monitoring costs must not be underestimated and only large institutional holders are able to reap economic benefits from continuously monitoring the top management.

In spite of the forgoing research papers, there still remains a lack of academic research regarding the effect of the presence of women on the board of directors of REITs. This paper attempts to fill this gap. In this paper, we constructed a corporate governance index where we included the following as the main variables: CEO entrenchment, the choice of having a staggered Board of Directors, and the presence of women in the Board of Directors.

Secondly, this paper studied the effect of institutional ownership on company performance. Though this field has been extensively researched, this paper differs from other papers in that it did not focus on the absolute number of institutional holders. Furthermore, this paper only used the percentage of the top 10 institutional holders. The outline of the paper is as follows. In Section II, we will provide a detailed review of the current literature regarding corporate governance and institutional ownership, and their effects on company performance. In subsequent sections, we present our hypothesis that we will test. In Section IV, the data used for the research and the methodology applied are described. In the last section, we conclude on this research.

\section{Literature Review}

Many authors have researched the effects that corporate governance has on a firm's performance. The main idea is that the presence of a qualitative corporate governance environment in a firm will lead to better performance resulting in shareholder wealth maximization. Therefore, this notion was supported by Core et al. (2006) and Gompers et al. (2003).

Campbell et al. (2009) stated that CEOs with longer tenures are more entrenched and less subject to discipline, which increases the firm's agency problems. Masulis et al. (2007) concluded that CEO duality is negatively related to a firm's value and performance. In a study conducted by Weisbach (1998), it was shown that CEOs become more entrenched during their career, resulting in the investment of higher bargaining powers in the board of directors. This ultimately influences the board's composition in favor of less external directors. The evidence reported by Hermalin and Weisbach (1998) is in line with the foregoing study. However, CEO entrenchment can be explained not only by tenure, but also by the institutional requirements present in the American legislature. To qualify as a REIT, at least 75 percent of the total assets must be real estate assets, cash and cash items, and U.S. 
government obligations. This restriction halts the possibility of inter-industry mergers and diversification types of investments. It offers a rather limited chance for investors to jump from other industries to the real estate industry, thus making the CEO position of a REIT as a relatively small market. Furthermore, it also means that current CEOs have all the incentives in place to try and "shield" themselves from external acquisitions.

The market for corporate control functions in such a way that it "punishes" poorly performing managers. When other firms or institutions see the opportunity to capitalize on positive or untapped projects and create positive synergies through an acquisition, they would not hesitate to engage in a hostile takeover. The mere existence of the threat, in theory, would discipline managers and make them perform adequately so as to eliminate such a risk. Nevertheless, Campbell et al. (2001) collected data for eighty-five mergers between publicly traded equity REITs and public/private target REITS in the 1990s. Also, they reported that all the deals were friendly and not a single one was a hostile takeover. This fact does stress the importance of independent and unaffiliated directors being present in the board so as to protect the interest of minority shareholders and third parties. Moreover, REITs are subject to the 5-50 rule which states that "five or fewer individuals cannot own more than 50 percent in value of the outstanding beneficial interest in the organization at any time during the last half of any tax year." Any shares that are acquired or controlled in excess of this provision will lose all voting privileges and be entitled only to economical remunerations. Being entities that generally invest in long-term projects (due to the nature of the real estate sector), the provision of potentially having more than 5 individuals for the first half of the year is at best symbolic. A related rule states that REITs must have "100 or more beneficial owners for 335 days of a full year." Therefore, the two rules mentioned above could potentially hurt the performance of firms because they do limit the ability to acquire a block holding percentage of shares. Requiring a diversified ownership base makes coordination and communication among shareholders a challenge. Furthermore, it lowers the chances of them forming alliances to govern the REIT and ultimately minimizes their ability to take actions against deviant manager behaviors.

Fama and Jensen (1983) identified independent directors to be very crucial and important for monitoring managers' activity. Specifically for REITs, a study conducted by Friday and Sirmans (1998) reported a positive relationship between the performance of an entity and a large independent director representation. Friday and Sirman (1998) proved in their research that there exists a positive effect between market-to-book ratio and the presence of outside directors in the board, specifically for REITs. Based on their work, one can conclude that an independent board is more likely to be associated with higher NPV projects. But for the REIT industry, this is not guaranteed because 
the regulator constraints require a real estate expertise and not just a general managerial ability to achieve positive returns on investments. Hermalin and Weisbach (2003) conclude that "there is little to suggest that board composition has any cross-sectional relationship with firm performance."

The legal requirements to which REITs have to adhere to, granted them distinct features when compared with other firms. However, the internal structure of REITs has undergone major changes in the last two decades. A study conducted by Ling and Ryangert (1997) showed that REITs of the 1990s have a higher level of insider and institutional shareholding. They display a different management style and organizational structure. According to Ling and Ryngaert (1997), such changes have crucial implications when it comes to firm valuation. This is because a greater presence of institutional holders could facilitate takeover, lower monitoring costs for smaller shareholders, and increase management scrutiny. Ultimately, REITs could benefit from a reputational spillover of having large investors investing in their company. Chan et al. (1998) documented a very interesting trend. During the 1990s, institutional investors have invested more in REITs than they have in any other type of stock. According to their results, such ownership change have had a positive impact on a firm's performance.

According to Feng et al. (2005), two of the main characteristics of qualitative corporate governance are the size and the presence of outside directors. Starting with the size, it has been observed generally that a smaller board is more able to deliver better financial performance and is associated with better and faster decision making. Certainly, it is easier for a smaller board to agree on the implementation of defensive mechanisms e.g. poison pills and to set CEO's compensation. The process of appointing and/or removing a CEO is also faster and more effective. Eisenberg et al. (1998) concluded that "firms with small boards have better financial ratios and presents stronger monitoring to CEOs." This relationship is present in small firms. Consequently, one of the most widely used measures of investment performance is Tobin's Q. Yermack (1996) found a negative relationship between this indicator and board size, implying better investment decisions for smaller boards of directors. The relationship also holds beyond the American shores as shown by Mak and Kusmandi (2004) in their research about Singaporean and Malaysian firms. Feng et al. (2005) found that "smaller boards are associated with higher 5-year average returns on assets." Campbell et al. (2009) found that larger boards are less effective in monitoring the management of the firm. Jensen (1993) concluded that large boards suffer from the lack of cohesion and coordination, resulting in slow decision making and an inability to voice disapproval concerning deviant managerial behaviors.

Therefore, the second characteristic that influences the credibility and decision making quality of the board is the presence of independent directors. 
Their presence is very important for the monitoring purposes as they are not affiliated with the enterprise in any other form apart from their directorship. In theory, the appointment of such directors would means that the interest of the minority shareholders is safeguarded and so is the viability of the enterprise. Thus, because they are not employees of the firm, the CEO's influence on them is thought to be rather limited. Cotter et al. (1997) conducted a research on the role of independent directors during a takeover attempt. Their research identifies a positive effect on the "offer premium, bid premium revision, and target gains" during the takeover process. They concluded that the presence of independent directors does indeed "enhance target shareholder gains." In an earlier study, Rosenstein and Wyatt (1990) proved the existence of a positive relationship between stock price reactions and the appointment of independent directors. They attributed such a positive market reaction to the expected increase in the quality of monitoring performed by the board on the CEO. In addition, the committees are another aspect where the appointment of outside directors has positive effects. According to Klien (1998), the quality and effectiveness of committees are far better with a larger presence of independent directors. Yet, Feng et al. (2005) found that the "presence of outside directors has a weak impact on firm's performance." Bhagat and Black (2002) conducted a research that stretched from the 1980s to the early 2000s and concluded that "the impact of the board of directors on performance is anything but resolved." They argued that asking the board members to focus solely on monitoring tasks comes with a trade-off. Hence, they will be required to perform less advisory duties which could in itself, diminish shareholders' wealth instead of increasing it.

Generally, there is a consensus in the literature on this subject regarding the relationship between firm's performance and ownership by directors and managers (Kim et al., 1988; Pfeffer, 1972; and Vance, 1964). Schellenger et al. (1989) found a positive relationship between stockholding of directors and various measures of performance. Oswald and Jahera (1991) presented evidence in their study that showed a significant relationship between ownership and financial performance. More recently, Khorana et al. (2007) examined the impact of ownership on fund performance, and concluded that future risk-adjusted returns are related to managerial ownership. Smith and Watts (1992) argued that restricted investment opportunities per se help mitigate agency problems due to the inability of managers to diversify into different business areas. As such, the REIT industry allows for the proper evaluation of the performance of the CEO and the managing team through firm's performance. This is because their motivation variation is nearly eliminated and the set of investment opportunities that they face is rather limited compared to a normal entity or an M-form organization. Nevertheless, that does not eliminate the moral hazards and the desire to reap 
high economical profits. Jensen (1986) developed the so-called "free cash theory." According to this theory, agency problem is severe in companies where the CEO and the managerial body have access to significant amounts of cash flows. REITs operate in the real estate sector, and the rental income comprises of a substantial part of the total income and as such would potentially give a big pool of funds to managers which they could abuse. To compound the problem, REITs do not pay taxes. However, the regulatory environment tackles this problem through a provision where it is required to pay out "at least $90 \%$ of taxable income." This eliminates to a certain extent the problem described by Jensen (1986). It may also reduce the incentive to have a large portion of the board composed of outside directors. According to Ghosh and Sirmans (2004), dividends and board monitoring can be considered as substitutes for each other. This implies that a high level of cash disbursement lowers the need for having an independent board of directors.

A potential solution to ensure that managers are enlightened about shareholders is to grant stock ownership to the former. This seems like a very good option and would lower the cost of constantly monitoring CEOs on behalf of shareholders. However, the academic findings show a weak relationship between insiders, more specifically CEOs and highly ranked managers, and positive, or even sub-normal performance. Friday et al. (1999) concluded that there is a positive relationship between market-to-book ratios and insider ownership, only that it is holds true for low levels of ownership. Ghosh and Sirmans (2003) conducted a study of 122 US equity REITs and reached the conclusion that block ownership, independent directors, and institutional ownership do not significantly affect nor do they strongly enhance a company's performance. They found a weak relationship between performance enhancement and outside director representation on the board of director of REITs. Institutional ownership failed to serve, in their view, as an "alternative discipline mechanism" that would offset potential inadequate monitoring by outside directors. They also concluded that CEOs do "exert a greater influence both on the board composition and performance, than outside directors do." This later finding can explain the fact that REIT CEO compensation is higher on average for boards where monitoring is weak. Hence, the board is composed of a larger number of directors who are generally old.

\section{Hypotheses} be tested:

Based on the summary of literature, we developed two hypotheses to 1. Because literature had no consensus on the effect of corporate governance, we developed an Index where we included a variable that captured the presence of women on the Board of Directors. This topic had 
not been investigated in the context of REITs before. To the best of our knowledge, this is the first attempt to do so

2. We tested the effect of institutional ownership on the financial performance of companies. The institutional ownership level was not taken at absolute levels, but we concentrated on the top 10 institutional holders.

\section{Data and Methodology Summary Statistics}

Summary statistics of 105 Real Estate Investment Trusts (REITs) are presented on a yearly basis from 2007 to 2012 in Table I (a-g). There was a total of 21 REITs who invested in apartments, 12 are diversified, 6 focused on healthcare, 12 invested in hotels, 15 in offices, 11 in others, and 28 invested mostly in retail. First, the study found that the REIT board (BRDSIZE) had an average of 8 board members which lines up with the findings of Campbell et al. (2009). Regarding the average number of outsiders (NMOUTSIDER) present in the board, the above mentioned paper differs from this paper in that it was 5; whereas in this paper, it was 7. The percentage of outsiders (PCTOUTSIDER) siting in REIT boards was $85.50 \%$ which lines up with conventional firms as reported by Ferry (1999), and is higher than those reported for the REITs in other studies. This indicator clearly shows the influence of the growing academic work that "sponsors" an outside denominated board. At the same time, the legal framework in the United States has been changing in favor of increasing the quality of corporate governance, especially for large public corporations. Following the demise of major global companies such an Enron and WorldCom due to accounting scandals and other inappropriate ethical work, The Sarbanes-Oxley Act was approved by the American legislation. However, the aim of such acts is to reduce such inefficiencies. The late financial crisis led to the Dodd-Frankly Act, which is another legislative piece that tries to reduce deviant behavior among top ranked corporate managers. Following the board of directors descriptive results, the database used for this research showed that nearly one-fourth of them are staggered boards (STGRDBRD). This confirmed the view that the hostile takeover market is nearly inexistent in the REIT industry.

This paper revealed another variable that is lacking in other academic work on the subject, which is the average period of time that board members (TENUREBRD) serve in their positions. For the 105 companies that were investigated, the tenure stood at nearly 10 years. The average tenure of the CEO (CEO_TENURE) stood at 9 years. A REITs board member's mandate is generally four years. However, on the average, they spend twice as much time in this position. Certainly, being part of the company for such a long period of time creates problem in terms of board efficiency. As reported by Feng et al. (2005), many directors are chosen and/or designated by the CEO. 
In the database used for the construction of this paper, the number of board members who joined after the appointment of the CEO was 364 or $42 \%$ of the serving directors as of $31^{\text {st }}$ of December, 2012. Therefore, they have either been appointed directly by the CEO or have been active in their selection procedure.

CEO duality (CEO_CHAIRMAN), meaning that the Chief Executive Officer serves as the Chairman of the board as well, was presented to be around 50\% (Campbell et al., 2009). This study showed that this ratio has dropped to $39 \%$, which is a slight but not significant change. Furthermore, this study views CEO entrenchment from two other innovative perspectives. First, it investigated the percentage of CEOs who aside from being the chief executive officer, were also founders of the company (CEO_FOUNDER). It was discovered that from a sample of 105 REITs that the ratio stood at $10 \%$. Secondly, this study investigated the number of CEOs who served as Chairman in addition to founding the company (CEO_CHAIRMAN_FOUNDER). The ratio stood at 8\%. The numbers indicate that even though REITs are a closed-end fund specialized only in one investment segment and for which specific management abilities are required, the different combination of CEO entrenchment are below the fifty percent threshold. Furthermore, the trend is towards a lower CEO entrenchment.

In order to align the interests of the principals (shareholders) and agents (managers), it was argued (Shleifer and Vishny (1997)) that granting ownership in the form of stocks to the CEO and other highly ranked managers would ensure that they do not misbehave. Instead, they would "chase" down positive projects because they would profit financially themselves. The insider ownership (INSIDER_OWN) level stands close to 8\%. Normally, in a publicly traded U.S corporation having more than $5 \%$ of the outstanding shares, grants to the holder a so-called blocking percentage. However, this number must be interpreted cautiously and in the light of the other variables concerning REITs. It is not necessarily a bad sign, especially in the absence of hostile takeovers. On the contrary, such a high percentage of insider ownership can help facilitate transactions.

Institutional ownership is perceived as a positive indicator for both the company and minority shareholders. Being generally very large financial institutions and having access to excessive amounts of capital, they can affect the reputation of a corporation and help reduce its borrowing costs, thereby facilitating access to money markets. In this study, institutional ownership refers to the top ten institutional holders (INSTITUT_OWN). The average institutional ownership was close to $32 \%$. The ratio has been increasing dramatically from $17 \%$ in 2009 to $50 \%$ at the end of 2012 . Thus, the reason this study focuses on the top 10 institutional holders is due to coordination in terms of decision making. Tying this finding with the ownership test, which is 
as required by the U.S. legislation, a REIT must have at least 100 owners. Therefore, having such a threshold is a logical and suitable one. The average number of institutional holders is much higher. At around 180, it further strengthens the decision making ability of the top 10 institutional holders. Thus, the institutional holders owning one-third of the outstanding stock does not grant them pure and numerical control. However, it allows for effective control. As such, these investors can agree to appoint or remove CEOs when they find it reasonable to do so. As expected, the higher the percentage of institutional ownership, the lower the percentage of the insider's stake in the firm.

The introduction of a mandatory requirement of having a women on the board of directors of all Norwegian firms led to an underperformance of the companies and the damaging of the performing ability of the board of directors. A 2012 report published by Credit Suisse provided conclusive evidence that showed the positive effect of the presence of free-will women on the board of directors. Therefore, to further study the effects of women, the researcher included a dummy variable (WOMENBRD) that describes the funds that have at least a women on board and those that do not. From 105 REITs that were investigated, only 3 have a woman as a Chief Executive Officer. Also, an overall of 83 women were serving on the boards. It is very interesting to note that the background of two-third of the women serving as board members was not real estate. The average tenure of the female board members was 5 years (TENUREWOMEN), which is half of the entire REIT average. Furthermore, there is a big concentration of women being appointed as REITs board members for the first time only in the last decade. As of 2012, forty-five Real Estate Investment Trusts did not have women on their boards.

As an indicator of financial performance, the returns on average on assets (ROAA) was used. The variable was calculated as net income as a percent of average assets. For the year 2007, the ROAA was calculated using the net income of 2007 and the assets value of 2006 and 2007. The same calculation methodology was used for the coming years, up to 2012. The average of the return on assets (return on average of assets and returns on assets are used interchangeably in this paper) for the period 2007-2012 was $2.01 \%$. The higher value was recorded at $3.73 \%$ for 2007 , and the lowest value was $0.79 \%$ for the year 2009. Subsequently, a second indicator is the return on average of equity (ROAE). The variable was calculated as net income as a percentage of average equity. For the year 2007, the ROAE was calculated using the net income of 2007 and the equity value of 2006 and 2007. The same calculation methodology was used for the coming years up to 2012. The average of the returns on equity (return on average of equity and return on equity are used interchangeably in this paper) for the period 2007 to 2012 was $4.59 \%$. The higher value was $12.88 \%$ in 2007 , while the lowest value was 
$1.07 \%$ in 2009 . This indicated a very large variety which is not only due to the financial crisis, but also due to the changes in the ownership structure as well.

Therefore, to avoid any statistical insignificance, the market capitalization (MARKETCAP), which is on average $\$ 2.8$ billion, and the liabilities ratio (TD/TA), which stands at an average of $0.53 \%$, were used as control variables.

\section{Univariate Analysis: Corporate Governance Index}

Bauer et al. (2009) conducted a study of 5000 US companies and found a strong and positive relationship between the corporate governance index they used. They also find the financial performance, which is measured by several variables. When performing the same test on a sub-set of companies composed out of REITs, the author found no significant relationship between the corporate governance index and the financial performance. The explanation for such a finding relates to the fact that REITs operate in a very restrictive regulatory environment, and as such, the effect of corporate governance does not translate into higher financial performance. On the other hand, a study conducted by Feng et al. (2005) followed the same principle. In order to construct their corporate governance index, they use three variables: a) board size, b) CEO duality, and c) the presence of outside directors in the board of directors. The results presented by the authors showed that firms with a higher corporate governance index were "associated with a higher 5-year average ROA." The review of literature is certainly mixed, and no solid conclusion can be drawn so far. This paper attempts to bring further evidence regarding the effect of corporate governance on firm's performance.

In order to capture the effects of corporate governance and to see its relationship with the financial performance of the fund, the author constructed the Corporate Governance Index (CG-Index). First, the CEO entrenchment is included. Masulis et al. (2007) concluded that CEO duality is negatively related to a firm's value and performance. Therefore, the same conclusion was reached by Feng et al. (2005). The reason why CEO entrenchment is part of Corporate Governance was due to the fact that a CEO who takes on the task of the Chairman of the Board is too powerful. He has the ability to influence decision making which could by itself potentially hurt the performance of the firm. Two other studies, Hermalin and Weisbach (1998) and Weisbach (1998), found evidence that the Chief Executive Officer becomes more entrenched throughout his career if his tenure is long. This would mean that the bargaining power of the board members would be lower relative to that of the CEO who would later ultimately be able to affect the composition of the board. In this study, the characteristic of a founding CEO was added. The reason for such an inclusion is that if a CEO is a founder, he has "natural" ties with the firm and with the employees. In a dear situation, this could be a very good thing because 
the individual can symbolize leadership and affect the firm for good. In other cases, the relationship can work in the opposite direction. If the Chief Executive Officer performs only this task and sits in the board of the directors without being the Chairman, 1 point is added to the CG-Index. If the CEO is also the Chairman of the board or is one of the founders, 0.5 point is added to the CG-Index. If the CEO is the Chairman of the board and is one of the founders of the entity, 0 point is added to the CG-Index.

Bebchuk et al. (2010) concluded that the presence of a staggered board is negatively related to a firm's valuation. The findings are supported by the studies of Faleye (2007) and Masulis et al. (2007). Nonetheless, it is important to note that their study was conducted on normal corporations and not on REITs. The results are understandable because a staggered board does indeed lower the ability for takeovers to be completed successfully. Therefore, it could jeopardize the firm's value from this angle. However, the results need not be true to a universal level. The REIT environment is very different. There is virtually no hostile takeover market and as such, the presence of a classified board does not hurt the firm's value. Therefore, it is interesting to see the effect of a classified board of directors on the financial performance of REITs. In addition, the presence of a classified board adds 1 point to the CG-Index, otherwise 0 is added.

Nielsen and Huse (2010) argued that group diversity can lead to potential increases in the levels of conflicts. On the other side, the authors recognized that based on gender theories, "women are more sensitive towards the needs of others, better able to resolve interpersonal conflicts, and often engages in more participative leadership styles." Luckerath-Rovers (2010) conducted a study of 99 Dutch listed companies and found that companies with female board members do indeed perform better than those without one. Furthermore, Singh and Vinnicombe (2004) argued that higher financial performances can be achieved because the presence of women on the board of directors is a "consequence of a more innovative, modern, and transparent enterprise." Another positive effect of increased female board members was reported by Rose (2007) who indicated that "female employees are more motivated" to perform better on the job. In a report titled 'Gender Diversity and Corporate Performance' which was published in 2012 by the Credit Suisse Research Institute, it was noted that the female board members have a significant effect on company's performance. The study was conducted on 2500 U.S. firms for the period of 2006 to 2011. The paper showed that companies with at least a women on the board had a ROE of $16 \%$ for a period of 6 years, while the companies that had no woman on the board had a ROE of $12 \%$ for the period of 2006 to 2011.

This paper made an attempt to see the effect of the female board members, whether it has a positive or negative relationship with financial 
performance (see Table V). To the best of our knowledge, this is the first study that uses such a variable as part of its corporate governance indicators in the Real Estate Investment Trusts of firm samples. The presence of women on the board of directors is signaled with 1 point, while the absence is 0 point.

The funds were separated into three groups. CG-Index $=3$ was composed out of 33 funds. This group scored 3 out of 3 in terms of the CGIndex. The average return on assets for the period 2007 to 2012 was $3.17 \%$. Group 2, CG-Index = 2, was composed out of 51 funds. This group scored 2 out of 3 in terms of the Corporate Governance Index and had a return on average on assets of $1.98 \%$. The last group, CG-Index $=1$, was composed out of 21 companies. This group had a score of 1 and a return on assets of $1.47 \%$, on average, for the period 2007 to 2012. Clearly, the improvement of the corporate governance quality is associated with significantly higher returns on assets. Yet, this is a simple univariate regression, and as such, it should not be taken at par value. It is used to show the sign of the relationship, while the real magnitude needs to be tested in other circumstances. This means that in a multivariate regression, other variables could potentially explain the outperformance and not necessarily the quality of corporate governance.

\section{Univariate Analysis: Institutional Ownership}

Institutional ownership has been attracting a fair amount of attention in terms of academic work due to the monitoring tasks that they perform or are expected to perform on top management. Shleifer and Vishny (1986) identified in their paper the greater incentive that these institutions have to monitor the CEOs and the management of the firm, and that this monitoring incentive is much higher than that of the board members. The reasoning behind this lies in the fact that the board members have very little or no wealth invested in the firm, while large investors come with considerable equity investments. Grossman and Hart (1980) argued that monitoring costs are, on average, high for big companies. Therefore, only large institutional investors will be able to reap the economic benefits from a constant monitoring of the firm's decisions and chosen investment projects. Several studies (McConnell and Servaes (1990); Nesbitt (1994); and Smith (1996)) have tested institutional ownership effect on monitoring, and have found evidence of this effect. More specifically, corporate monitoring by institutional investors will result in better corporate performance. It will limit managers' engagement in opportunistic and/or deviant managerial behavior.

On the other hand, there is a considerable amount of academic work that shows that institutional ownership and monitoring are not a positive linear relation. Graves and Waddock (1994) found that an increase in the level of institutional ownership has resulted in a decline in the performance of American companies. The authors argued that such a negative result is because 
institutional holders are expected to show a constant improvement in terms of results. Potentially, such improvements must be in every quarter. Maug (1998) argued that the amount of monitoring and enforcing decisions from institutional holders will be proportional to the size of the shares that they control. From this reasoning, it can be deduced that if the percentage of shares controlled by the institutional holders is significantly high, shares will most probably be held for longer periods. Hence, their marketability will be lowered. This by itself will induce higher monitoring. Certainly, the inverse relation is also true. If an institutional investor holds a lower stake in the firm, he/she will look for opportunities to shorten the stock and get a grip on potential buy-sell price differences. Various academic papers (Bhide (1994); Coffee (1991); and Demirag (1998)) have concluded that institutional investors are motivated by two factors that outweigh the benefits of constant monitoring. First, desiring highly-liquid assets under their management will mean that they will be less willing to engage in long-term share controlling. Second, the desire of short-term profitability are very significant elements in institutional decision making framework. Apart from the activism that institutional holders show through constant managerial monitoring, another very important aspect where considerable academic work has been channeled is the relationship with the firm's performance. McConnell and Servaes (1990) found in their research that the ownership of institutional investors is associated positively with a firm's Tobin's Q, a widely used measurement of investment performance. Other studies (Del Guercio and Hawkins (1999); Nesbitt (1994); and Smith (1996)) have found positive and statistically significant relationships between the presence of institutional investors and the performance of firms. On the other hand, studies conducted from Agrawal and Knoeber (1996) and Faccio and Lasfer (2000) have concluded that there is no significant relationship between the performance of companies and the presence of institutional holders.

Moreover, this paper tackled the institutional ownership and its effect on company performance from a different angle. First, the industry chosen for study purpose was the real estate industry and the sample firms were 105 U.S. Real Estate Investment Trusts. Due to the regulation present in the United States, which applies specifically to this type of entities (see Table I), the results can be expected to differ from other forms of entities. The ownership test states that $50 \%$ of the outstanding shares of a REIT cannot be owned by five of fewer individuals/companies. Furthermore, a REIT is obliged to have at least 100 different owners of the outstanding shares. This implies a very disperse ownership structure. Such a structure will lead to corporations or group of corporations having effective control over the firm. Effective control is considered to be such that an individual/entity or a group of individuals/entities can influence decision making without controlling more 
than $50 \%$ of shares. Thus, this threshold is typically around $30 \%$ up to $50 \%$.

Another benefit of having such a level of stock ownership is the limited monitoring that the individual/company has to perform. In this study, ownership was not simply taken at an absolute level. The percentage ownerships of the top 10 institutional holders were aggregated. The reason for such an approach is tied to the coordination problem. If there are 10 individual institutions that have a significant portion of the stake of a REIT, then the probability of them having a fast and well processed decision is much higher than having 100 shareholders and asking them to vote on a particular policy. Hence, this could lead to a positive spillover effect. If the large shareholders collude and "publicly" agree on a specific issue, then the minor shareholders will be more prompt to follow. This by itself is effective control, without paying an extra premium for it.

Three groups based on the percentage of the ownership level were created (see Table V). The first one was composed of REITs where the ownership level of the top 10 institutional holders stood at levels equal to or below $30 \%$ of the outstanding shares. The second group was composed of REITs where the ownership level of the top 10 institutional holders stood at levels equal to $30.01 \%$ and up to $50.00 \%$. The last group was composed of REITs where the ownership level of the top 10 institutional holders stood at levels equal to more than $50.00 \%$ of the outstanding stock. It is very interesting to note that by 2012, only the top 10 institutional holders have built a stock position in the excess of $50.00 \%$. The results are presented in Table V. The funds grouped in the second group constantly outperform the funds of the third group. The difference is largest in 2012 with more than $2.00 \%$, in terms of return of assets. Consequently, there was a better performance from REITs where top 10 institutional holders had a position between $30 \%$ and $50 \%$. On average, for the period of 2009 to 2012, the outperformance was $1.45 \%$ in terms of yearly returns on assets.

The findings confirmed the view that proportionate to their holding on a company, the institutional holders will engage in monitoring activities that lead to healthy financial results. The lack of large stock positions can be explained with the fact that these institutions do not want to have pure control of the fund. They want to be able to exercise active control which can be achieved in public companies with an ownership level of around 40\%. Having a dispersed ownership structure makes it possible for such an effective control to be enforceable. Yet, this is a simple univariate regression; and as such, it should not be taken at par value. It is used to show the sign of the relationship, while the real magnitude needs to be tested in other circumstances. This means in a multivariate regression, other variables could potentially explain the outperformance and not necessarily the stock ownership level of the largest institutional holders. 


\section{Multivariate Regression: Corporate Governance Index}

The authors interpret the univariate regression results as solid evidence of the positive effect of good corporate governance on the performance of Real Estate Investment Trusts. A lowly entrenched CEO, the presence of a classified board of directors, and the appointment of female board members lead to higher return on average for the study period of 2007 to 2012 for the 105 REITs used in this paper. However, such a simple regression fails to capture the effect of other potentially explanatory variables. In the multivariate regression, the ROA is the dependent variable and the explanatory variables are the CG-Index: the size of the Board of Directors; the length of time the CEO has been in his current position; and the level on insider ownership. $R O A A=\alpha+\beta 1 \_B R D S I Z E+\beta 2 \_C E O \_T E N U R E+\beta 3 \_C G-I N D E X+$ $\beta 4 \_I N S I D E R \_O \bar{W} N+\beta 5 \_M A R K E T C A P+\beta 6 \_T D / T A+\mu$

According to Campbell et al. (2009), large boards are less effective in monitoring the CEO and the top management. This is simply because it is more difficult for them to coordinate among each other and perform their task thoroughly. In a study conducted by Guest (2004) using a sample of 2746 UK listed companies over the period of 1982 to 2002, the author found that "board size has a negative and strong impact on profitability." The study used Tobin's Q and share returns as measure of financial performance. The findings were confirmed by Feng et al. (2009) who found a positive relationship between small boards and better financial performance. Eisenberg et al. (1998) concluded in their paper that "firms with small boards have better financial ratios and present stronger monitoring to CEOs". Therefore, to see what this relationship holds in our sample, we included the board size (BRDSIZE) as an independent variable. To further see whether powerful CEOs with a longer tenure will impact the financial performance of firms, a variable was included in the multivariate regression (CEO_TENURE).

In order to align the interests of the principals (shareholders) and agents (managers), it was argued (Shleifer and Vishny (1997)) that granting ownership in the form of stocks to the CEO and other highly ranked managers would ensure that they do not misbehave. Rather, they would "chase" down positive projects because they would profit financially themselves. Arosa et al. (2011) conducted a study of 586 private Spanish firms and found that insiders and managers become entrenched at high levels of stock ownership. Nonetheless, the relationship is healthy at relatively low levels of ownership from insiders. Kaserer and Moldenhauer (2005) found a strong and solid relationship between corporate performance and insider ownership at a level around $5 \%$ of outstanding stock. In order to capture these potential effects, the insider ownership level (INSIDER_OWN) was included in the equation as an independent variable. The market capitalization and the liabilities ratio were 
used as control variables. However, the results were summarized in Table XX.

For all the regressed variables, the logarithmic value was generated. After being converted to percentage variables, the regressions was run using Stata software. For the dummy variable, CG-Index, an increase in terms of scoring 1 leads to a yearly improvement of the return on assets of up to $0.30 \%$. The result is statistically significant at a $10 \%$ significance level. The board size and the company performance are negatively related, confirming literature prediction. On an average, the increase in the board size by 1 for boards with a size of 10 or more will lead to a decrease in the return of assets equaling $1.17 \%$ on a yearly basis. The result is statistically significant at a $1 \%$ significance level. The percentage of insider ownership and the length of the Chief Executive Officer's tenure have very little or nearly no impact in terms of financial performance.

In order to check the findings of this study, the author ran another regression. This time, the dependent variable was the return on average on equity (ROAE).

$R O A E=\alpha+\beta 1 \_B R D S I Z E+\beta 2 \_C E O \_T E N U R E+\beta 3 \_C G-I N D E X+$ $\beta 4 \_I N S I D E R \_O W N+\beta 5 \_M A R K \bar{E} T C A \bar{P}+\beta 6 \_T D / T A+\mu$

For a summary of the results, please see Table XX. The relationship did not change. The increase of the CG-Index by 1 point led to higher returns on equity with an average of $0.23 \%$ per year. The increase of a 10 or more member board of directors by 1 will lead to a decrease in the return on equity of up to $1.25 \%$ a year. The results are significant at $1 \%$ and $10 \%$ significance levels respectively. The relationship between the insider ownership levels and the tenure of the Chief Executive Officer are statistical insignificant and very low in terms of absolute values.

\section{Pooled OLS Regression}

Following the results of the univariate and multivariate regression regarding the effect of corporate governance quality on the performance of the companies and the results of the univariate regression on the effect of institutional ownership on firm performance, we ran a Pooled OLS Regression to test the results. The results are summarized in Table XX. The number of observations was 404. The new variables included in the regression were the length of time that board members had remained directors (TENUREBRD) and the number of outside directors appointed to the board (NMOUTSIDER). Because this is a time series regression, a dummy variable was constructed for each year (D_2007-D_2011).

$R O A A=\alpha+\beta 1 \_B R D S I Z E+\beta 2 \_C E O \_T E N U R E+\beta 3 \_C G-I N D E X+\beta 4$ INSIDER_OWN +

$\beta 5$ INSTITUT_OWN $+\beta 6_{-}$TENUREBRD $+\beta 7_{-}$NMOUTSIDER + $\beta 8_{-}$MARKETCA $\bar{A}+\beta$ 9_TD/TA $+\mu$ 
The first regression was run with the Corporate Governance Index being part of it. The results showed that the CG-Index was significant at a $1 \%$ confidence level with a coefficient of $0.92 \%$. This means that an increase in the score of Corporate Governance by 1 will lead on average to a $0.92 \%$ return on assets, which rises higher on an annual basis. Furthermore, the tenure of board members was statistically significant at 15 confidence level with a coefficient of $0.51 \%$. This means that an increase in tenure of board members will lead to higher average return on assets. Confirming the findings of the univarite regression, the institutional ownership was significant at a $5 \%$ confidence level. The coefficient was very high at $2.86 \%$, but the standard error was high as well, $1.48 \%$. The coefficients are insignificant for insider ownership and board size. This strengthens the view that the constructed CGIndex captures very important aspects of the corporate governance of REITs and that institutional ownership is a very influential tool in the performance of companies.

Furthermore, I perform a check by re-running the regression. But this time, we use the returns on equity as the dependent variable.

$R O A E=\alpha+\beta 1 \_B R D S I Z E+\beta 2 \_C E O \_T E N U R E+\beta 3 \_C G-I N D E X+\beta 4$ INSIDER_OWN +

$\beta 5$ INSTITUT_OWN $+\beta 6_{-}$TENUREBRD $+\beta 7_{-}$NMOUTSIDER + $\beta 8 \_$MARKETCAP $+\beta$ 9_TD/TA $+\mu$

The CG-Index shot up to $3.29 \%$ and it was significant at $1 \%$ confidence level. The coefficient for the institutional ownership sky-rocketed to $17.43 \%$, although it had a very high standard error of 7.10. The results were significant at $1 \%$ confidence level. The relationship was confirmed for the tenure of board members as well with a coefficient of $1.98 \%$. The number, though much higher when compared with the findings of the returns on assets, certainly serve as a solid proof of the positive relationship that exists between specific aspects of corporate governance and institutional ownership and their effects on financial performance.

In the second regression, the CG-Index was split into three parts. $R O A A=\alpha+\beta 1 \_B R D S I Z E+\beta 2 \_C E O \_T E N U R E+\beta 3 \_C E O \_C G-I N D E X$ $+\beta 4$ INSIDER_OWN $+\beta 5_{-}$INSTITUT_OWN $+\beta \overline{6}_{-}$TENUREBRD + $\beta 7_{-}{ }_{\text {NMOUTSIDER }}+\beta 8_{-}^{-}$WOMENBRD $+\beta 9_{-}^{-}$STGRDBRD + $\beta 1 \overline{0} \_$MARKETCAP $+\beta 11 \_T \bar{D} / T A+\mu$

Female board members were captured by one variable (WOMENBRD). The choice of having a classified board of directors or not was on its own a different variable (STGRDBRD). Thus, the entrenchment of the CEO was under the CEO_CG-Index. All the above mentioned variables were dummy variables that took a value of 1 or 0 . Hence, the results are summarized in Table IX. Institutional ownership was positively correlated with returns on assets. The coefficient stood at $2.88 \%$ and it was significant at 
5\% confidence level. Yet, the standard error was 1.63 which scaled down the magnitude of the result. The tenure of board members was positively correlated with a coefficient of 0.41 and was statistically significant at $1 \%$ confidence level. The presence of women on board led to an improvement in returns on assets of up to $0.99 \%$ a year. The result was statistically significant at $1 \%$ confidence level and the standard error was very little at 0.40 . The presence of a staggered board was also positively related with the firm's performance. REITs that opt for a classified board had an improvement of their returns on assets with $1.16 \%$. Hence, the result was statistically significant at $1 \%$ confidence level.

$R O A A=\alpha+\beta 1 \_B R D S I Z E+\beta 2 \_C E O \_T E N U R E+\beta 3 \_C E O \_C G-I N D E X$ $+\beta 4 \_$INSIDER_OWN + $\beta 5_{-}$INSTITUT_OWN + $\beta 6_{-}$TENUREBRD + $\beta 7_{-}{ }_{\text {NMOUTSIDER }}+\beta 8_{-}$WOMENBRD $+\beta 9_{-}$STGRDBRD + $\beta 1 \overline{0} \_$MARKETCAP $+\beta 11 \_T \bar{D} / T A+\mu$

$\mathrm{e}$

The author performed a check by re-running the regression. This time, he used the return on equity as the dependent variable. All the results held, and there was no change in terms of coefficient sign. Institutional ownership, presence of women on the board of director, and the length of time board members have remained in their positions were all statistically significant at $1 \%$ confidence level.

\section{Robustness Tests}

The author performed additional tests to check for potential sensitive variables to the model as well as to determine if any other variable may capture more explanatory effects. First, using Tobin's $Q$ as a measure of performance, the researcher saw the same relationship with the CG-Index and the institutional ownership. The reason such variable does not lead to major result is that the return on assets are interchangeable in one; and therefore, the variety is minimal. Using other control variables, such as dividend payout ratio and free funds from operations, often leads to no statistically significant changes in terms of results.

\section{Conclusion}

The researcher examined 105 U.S. Equity Real Estate Investment Trusts for a period of 6 years from 2007 to 2013. It was discovered that for this sample, corporate governance had a positive and significant impact on financial performance. The variables that were used in the construction of the corporate governance index are the presence of women in the board of directors, the choice to have a classified board of directors or not, and the entrenchment of the CEO. This is the first study that uses the presence of women as a main indicator of the quality of corporate governance. 
Secondly, this paper finds that the presence of institutional holders has a positive impact on fund performance. The relationship is healthier for ownership levels between $30 \%$ and $50 \%$. Differently from other studies, the researcher used the ownership level of the top 10 institutional holders and not the absolute value of the total institutional holders.

Further research must be done regarding the presence of females on the board of directors. The effect of institutional holders has been widely discussed. However, approaching it from innovative angles, such as the one used in this paper, can generate interesting insights.

\section{References:}

Arosa, D. B., Iturralde, D. T., and Maseida, D. A. (2011). Insiders Ownership and Firm Performance. Empirical Evidence. International Research Journal of Finance and Economics

67.

Bauer, R., Eichholts, P., and Kok, N (2009). Corporate Governance and Performance: The REIT Effect.

Bebchuck, L. A., Cohen, A., Wang, C. C. Y. (2010). Staggered Boards and 'the Wealt of Shareholders: Evidence from a Natural Experiment. Harvard Business Review.

Biaco, C., Ghosh, C., and Sirmans, C. F. (2007). Corporate Governance and Firm Performance: Evidence from REITs.

Bhagat, S., and Black, B. (2002). The non-correlation between board independence and long term firm performance. Journal of Corporation Law 27, 231-274.

Bhide, A. (1994). Efficient markets, deficient governance: U.S. securities regulations protect investors and enhance market liquidity. But do they alienate managers and shareholders?

Harvard Business Review 72, 128-140.

Campbell, R.D., Chinmoy, G., and Sirmans C. F. (2001). The Information Conent Method of Payment in Mergers: Evidence from the Real Estate Investments Trusts (REITs). Real Estate Economics 29, 360-387.

Campbell, R.D., Ghosh, C., Petrova, M., and Sirmans, C.C. (2009). Corporate Governance and Performance in the Market for Corporate Control: The case of REITs. Journal of Real Estate Finance and Economics 42: 451-480.

Chan, S. H., Leung, W. K., and Wang, K. (1998). Institutional Investment in REITs. Journal of Real Estate Research 16, 357-374.

Coffee, J. (1991). Liquidity versus control: The institutional investor as corporate monitor.

Columbia Law Review 91, 1277-1368.

Core, J. E., Guay, W. R., and Rusticus, T. O. (2006). Does Weak Governance Cause Weak Stock Returns? An Examination of Firm Opertating Performance 
and Investors Expectations.

Journal of Finance 61(2), 655-687.

Cotter, J. F., Shivdasani, A., and Zenner, M., (1997). Do Independent Directors Enhance Target Shareholder Wealth During Tender Offers? Journal of Financial Economics 43, 195-218.

Demirag, I. S. (1998). Corporate Governance, accountability, and pressure to reform: An International study.

Eisenberg, T., Sundgren, S., and Wells, M. T., (1998). Larger Board Size and Decreasing Firm Value in Small Firms. Journal of Financial Economics 48, 35-54.

Faleye, O. (2007). Classified Boards, Stability and Strategic Risk Taking. Financial Analysis Journal 65, 54-65.

Fama, E., and Jensen, M. (1983). Separation of ownership and control. Journal of Law and Economics 65(1), 54-65.

Feng, Z., Ghosh, C., and Sirmans, C. F. (2005). How important is the Board of Directors to REIT Performance? Journal of Real Estate Portfolio Management 11(3), 281-293.

Ferry, R.M. (1999). Boardrooms yesterday, today, and tomorrow. Chief Executive Magazine 142, 44-47.

Finkelstei, S. and Hambrick, G.S. (1998). Top executives and their effects on organizations. West Publishing Company.

Friday, H. S., and Sirmans. G. S. (1998). Board of director monitoring and firm value in small firms. Journal of Real Estate Research 16(3), 411-427.

Friday, H. S., Mitchell, C. C., and Sirmans G. S. (1999). Ownership Structure and the Value of the Firm: The case of REITs. Journal of Real Estate Research 17, 71-90.

Ghosh, C., and Sirmans, C. F. (2003). Board independence, ownership structure and performance: evidence from the real estate market. Journal of Real Estate Finance and Economics 26(2), 287-318. 


\section{APPENDIX}

\section{Tabel I: Requirements to Qualify as a REIT}

The table provides a summary of the requirements from the legislation in the U.S. for a corporation to qualify as a REIT. These regulatory requirements are specific for this type of entity and differentiate them from other types of organizations.

Regulation name

Explanation

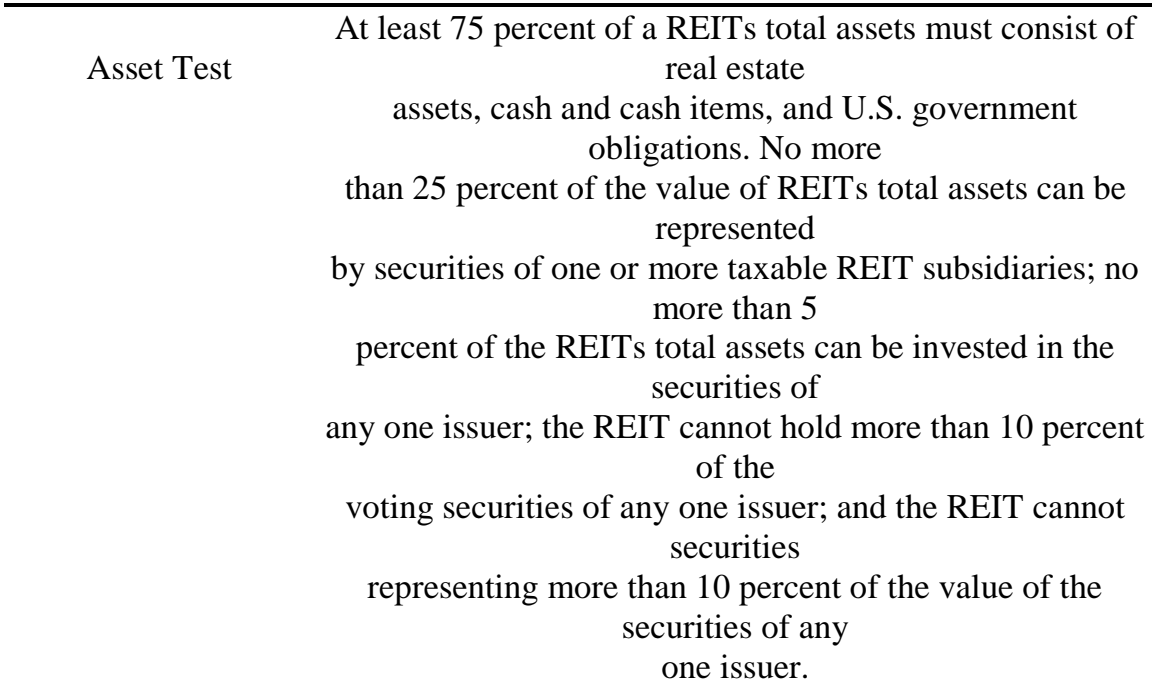

\section{Distribution Test}

To qualify for tax treatment as a REIT, the deduction for dividends paid must equal or exceed the some of: a) 90 percent of the organization's real estate investment trust taxable income determined without regard to the dividends paid deduction and by excluding any net capital gain; and b) 90 percent of net income from foreclosure property.

\section{Income Test}

\section{Ownership Test}

A REIT must derive at least 75 percent of its gross income from rents; interest on obligations secured by mortgages on real property or interests in real property. A REIT must derive 95 percent of its gross income from dividends, interest, rents from real property, gains from sales of stock, securities or real property and income from foreclosure property.

A REIT must have 100 or more beneficial owners for 335 days of a full year or a proportionate number of days in a short year. It cannot be closely held, five or fewer individuals cannot own more than 50 percent in value of 
the outstanding beneficial interests in the organization at any time during the last half of any tax year.

\section{Table III (a): Summary Statistics}

Summary description of the data used to analyze the performance of 105 US Equity REITs during the year 2007. The information has been collected from the Annual Reports of the specific companies as well as the SNL database. All companies are publicly traded US Real Estate Investment Trusts.

\begin{tabular}{|c|c|c|c|c|c|c|}
\hline Variable & Average & Median & S.D. & $\begin{array}{l}\text { Low } \\
\text { Value } \\
\end{array}$ & $\begin{array}{l}\text { High } \\
\text { Value }\end{array}$ & Skewness \\
\hline BRDSIZE & 8,28 & 8,00 & 1,74 & 5,00 & 13,00 & 0,13 \\
\hline NMOUTSIDER & 7,11 & 7,00 & 1,67 & 4,00 & 11,00 & 0,21 \\
\hline PCTOUTSIDER & $85,50 \%$ & $87,50 \%$ & $6,21 \%$ & $62,50 \%$ & $100,00 \%$ & $-1,24$ \\
\hline TENUREBRD & 9,74 & 9,00 & 3,90 & 2,00 & 24,00 & 0,79 \\
\hline WOMENBRD & 0,79 & 1,00 & 0,85 & 3,00 & 3,00 & 0,83 \\
\hline TENUREWOMEN & 5,38 & 4,00 & 5,27 & 0,00 & 19,00 & 1,16 \\
\hline STGRDBRD & 0,30 & 0,00 & 0,46 & & & 0,91 \\
\hline CEO_AGE & 55,90 & 56,00 & 8,31 & 34,00 & 81,00 & 0,42 \\
\hline CEO_TENURE & 8,92 & 8,00 & 6,13 & 0,00 & 26,00 & 0,55 \\
\hline CEO_CHAIRMAN & 0,39 & 0,00 & 0,50 & & & 0,46 \\
\hline CEO_FOUNDER & 0,10 & 0,00 & 0,31 & & & 2,62 \\
\hline CEO_CHAIRMAN_FOUNDER & 0,08 & 0,00 & 0,27 & & & 3,24 \\
\hline ROAA & $3,73 \%$ & $3,27 \%$ & $3,01 \%$ & $-1,32 \%$ & $17,83 \%$ & 1,46 \\
\hline ROAE & $12,88 \%$ & $9,04 \%$ & $22,48 \%$ & $-43,42 \%$ & $173,74 \%$ & 5,16 \\
\hline MARKETCAP & $2.929,02$ & $1.543,13$ & 3953,59 & 13,23 & $21.827,55$ & 2,58 \\
\hline TD/TA & $0,54 \%$ & $0,56 \%$ & $0,20 \%$ & $0,00 \%$ & $0,94 \%$ & $-0,94$ \\
\hline $\begin{array}{l}\text { INSIDER_OWN } \\
\text { INSTITUT_OWN }\end{array}$ & $7,56 \%$ & $2,29 \%$ & 0,12 & $0,25 \%$ & $64,20 \%$ & 2,82 \\
\hline
\end{tabular}

\section{Table III (b): Summary Statistics}

Summary description of the data used to analyze the performance of 105 US Equity REITs during the year 2008. The information has been collected from the Annual Reports of the specific companies as well as the 
SNL database. All companies are publicly traded US Real Estate Investment Trusts.

\begin{tabular}{|c|c|c|c|c|c|c|}
\hline Variable & Average & Median & S.D. & $\begin{array}{l}\text { Low } \\
\text { Value }\end{array}$ & $\begin{array}{l}\text { High } \\
\text { Value }\end{array}$ & Skewness \\
\hline BRDSIZE & 8,28 & 8,00 & 1,74 & 5,00 & 13,00 & 0,13 \\
\hline NMOUTSIDER & 7,11 & 7,00 & 1,67 & 4,00 & 11,00 & 0,21 \\
\hline PCTOUTSIDER & $85,50 \%$ & $87,50 \%$ & $6,21 \%$ & $62,50 \%$ & $100,00 \%$ & $-1,24$ \\
\hline TENUREBRD & 9,74 & 9,00 & 3,90 & 2,00 & 24,00 & 0,79 \\
\hline WOMENBRD & 0,79 & 1,00 & 0,85 & 3,00 & 3,00 & 0,83 \\
\hline TENUREWOMEN & 5,38 & 4,00 & 5,27 & 0,00 & 19,00 & 1,16 \\
\hline STGRDBRD & 0,30 & 0,00 & 0,46 & & & 0,91 \\
\hline CEO_AGE & 55,90 & 56,00 & 8,31 & 34,00 & 81,00 & 0,42 \\
\hline CEO_TENURE & 8,92 & 8,00 & 6,13 & 0,00 & 26,00 & 0,55 \\
\hline CEO_CHAIRMAN & 0,39 & 0,00 & 0,50 & & & 0,46 \\
\hline CEO_FOUNDER & 0,10 & 0,00 & 0,31 & & & 2,62 \\
\hline CEO_CHAIRMAN_FOUNDER & 0,08 & 0,00 & 0,27 & & & 3,24 \\
\hline ROAA & $2,18 \%$ & $2,17 \%$ & $3,40 \%$ & $-10,41 \%$ & $14,18 \%$ & $-0,23$ \\
\hline ROAE & $3,10 \%$ & $6,56 \%$ & $33,99 \%$ & $307,69 \%$ & $53,64 \%$ & $-7,74$ \\
\hline MARKETCAP & $2.284,15$ & $1.209,6831$ & 197,57971 & 11,28 & $18.826,18$ & 2,86 \\
\hline TD/TA & $0,55 \%$ & $0,58 \%$ & $0,20 \%$ & $0,00 \%$ & $0,99 \%$ & $-1,03$ \\
\hline $\begin{array}{l}\text { INSIDER_OWN } \\
\text { INSTITUT_OWN }\end{array}$ & $7,56 \%$ & $2,29 \%$ & 0,12 & $0,25 \%$ & $64,20 \%$ & 2,82 \\
\hline
\end{tabular}

\section{Table IV: Institutional Ownership and its effect on Financial Performance}

INSTITUT_OWN represents the percentage of shares owned by the top 10 institutional holders. INSTITUT_OWN > 50\% is a dummy variable generated to incorporate the funds, where the top 10 institutional holders own more than $50 \%$ of the outstanding stock. . INSTITUT_OWN > 30\% \& 50\% $<$ is a dummy variable generated to incorporate the funds, where the top 10 institutional holders own between $30 \%$ \& $50 \%$ of the outstanding stock. INSTITUT_OWN $<30 \%$ is a dummy variable generated to incorporate the funds, where the top 10 institutional holders own less than $30 \%$ of the outstanding stocks. ROAA Average is the simple arithmetical average from the year 2009 to the year 2012. The results clearly indicated that an ownership 
level between the $30 \%$ and $50 \%$ bracket is associated with a much better financial performance as measured by the returns on average, with a difference more than double compared with concentrated institutional ownership levels below 30\%. The evidence for concentrated institutional holders with levels higher than $50 \%$ is missing. It is only available for the year 2009 and that is much lower compared with the return on average for the funds where institutional ownership stands between $30 \%$ and $50 \%$.

The information regarding the years 2007 and 2008 was not possible to be retrieved and therefore the analysis is restricted only to the years 2009 , 2010, 2011 and 2012.

ROAA 2009 ROAA 2010 ROAA 2011 ROAA 2012 ROAA Average

INSTITUT_OWN

$>\mathbf{5 0 \%}$

na

na

na

$1,92 \%$

na

\section{INSTITUT_OWN}

$>30 \% \& 50 \%$ <

INSTITUT_OWN

$$
<30 \%
$$

